\title{
Pertunjukan Wayang sebagai Salah Satu Bentuk Ruang Mediasi Pendidikan Budi Pekerti
}

Suyanto

ISI Surakarta

\begin{abstract}
This article is an abstraction of my research entitled "Pendidikan Budi-pekerti dalam Pertunjukan Wayang" (Moral Education within Wayang Performance). The purpose of the research is to understand how far Wayang performance has a function as a speech of mediation of moral education especially for the young generation. Based on the pakeliran material of Lakon Begawan Ciptaning by Bambang Suwarno, it can be described that Wayang performance is a medium for moral education. "Lakon Ciptaning" has a value content which is able to become a source of inspiration on education of character building.
\end{abstract}

Key words: Wayang performance, moral education

\begin{abstract}
ABSTRAK
Artikel ini merupakan intisari dari hasil penelitian yang berjudul "Pendidikan Budi Pekerti dalam Pertunjukan Wayang". Penelitian tersebut dilakukan guna mengetahui sejauh mana pertunjukan Wayang berperan sebagai suatu mediasi pendidikan moral, terutama bagi generasi muda. Berpijak dari materi pakeliran pada Lakon Begawan Ciptaning sajian Bambang Suwarno, dapat diambil suatu gambaran bahwa pertunjukan Wayang merupakan suatu wahana pendidikan moral. Lakon Ciptaning memiliki kandungan nilai yang dapat menjadi sumber inspirasi pendidikan karakter.
\end{abstract}

Kata kunci: pertunjukan Wayang, pendidikan budi pekerti

\section{PENDAHULUAN}

Pendidikan adalah sarana untuk melakukan transformasi sikap dan karakter seseorang menjadi semakin dewasa. Ruang-ruang pewacanaannya dapat menjelma dalam berbagai hal, di antaranya pendidikan melalui lembaga formal, yang mempelajari ilmu pengetahuan dengan mengandalkan metode terapan. Pendi- dikan menjadi penting bagi setiap individu dalam menjalin hidup bermasyarakat dan berbudaya.

Budi-pekerti merupakan bagian dari kebudayaan yang mencerminkan kualitas moral dan kepribadian setiap individu dalam kehidupan bermasyarakat. Kebudayaan, salah satunya, merupakan sistem dalam kehidupan manusia yang mencakup sistem religi, sistem bahasa, sistem pengetahuan, sistem pencaharian, sistem kemasyarakatan, sistem bercocok 
tanam, dan sistem kesenian. Budi pekerti di dalam sistem kebudayaan manusia berkedudukan sebagai fondamen paling mendasar yang diletakkan pada semua aspek pendidikan (Koentjaraningrat, 1981: 202-209). Pendidikan mengarahkan manusia kepada cara berpikir cerdas dan rasional. Seperti tercantum di dalam pembukaan UUD 45, bahwa tujuan pendidikan nasional adalah mencerdaskan kehidupan bangsa dan melaksanakan ketertiban dunia berdasarkan perdamaian abadi dan keadilan sosial.

Melalui pertunjukan Wayang Kulit, manusia dapat mengambil pelajaran hidup, karena seni pertunjukan Wayang Kulit pada hakikatnya adalah cerminan pendidikan yang dibutuhkan oleh kehidupan manusia. Dalam memberikan pendidikan seni dan lingkungan, tidak berarti masyarakat dipaksa memahami suatu bentuk seni ataupun aliran seni. Namun yang lebih signifikan adalah bahwa nilai seni mampu menginspirasi masyarakat untuk menggerakkan daya rasional maupun daya emosionalnya sehingga mereka memiliki kualitas kecerdasan yang tinggi.

Wayang merupakan salah satu seni pertunjukan yang mengandung berbagai pesan pendidikan, baik dilihat dari wujud karakter tokoh-tokohnya, pertunjukan, maupun lakon-lakon yang disajikan. Kekuatan konvensional dalam Wayang banyak mempengaruhi budaya masyarakat, tidak sekedar lukisan yang digunakan sebagai hiasan dan kesenangan, lebih jauh Wayang menjadi pandangan hidup, keteladanan, dan harapan masyarakat.

Dipilihnya Lakon Begawan Ciptaning sajian Bambang Suwarno, karena dipandang memiliki banyak muatan pesan-pesan moral serta nilai-nilai yang berdampak signifikan pada pendidikan budi peker- ti. Namun demikian, bukan berarti pertunjukkan Wayang dengan lakon lainnya menjadi tidak penting. Dalam usaha mengungkap jaringan nilai dan simbol, tidak menutup kemungkinan lakon-lakon lainnya dapat digunakan sebagai pijakan sejauh masih memiliki relevansi dengan tema bahasan.

Artikel ini bertujuan untuk menunjukkan kandungan nilai-nilai budi pekerti dalam pertunjukan Wayang Kulit, khususnya Lakon Begawan Ciptaning sajian Bambang Suwarno. Pada gilirannya diharapkan Wayang betul-betul mempunyai kontribusi terhadap pembangunan karakter bangsa.

\section{PEMBAHASAN}

\section{Pertunjukan Wayang}

\section{1) Pelaku Pertunjukan}

Pelaku pertunjukan Wayang (Kulit) terdiri atas seorang dalang, pengrawit, dan swarawati atau pesindhen. Pada zaman dahulu pergelaran Wayang cukup sederhana, dengan menggunakan perangkat Gamelan Wayangan yang jumlahnya relatif terbatas sehingga jumlah pengrawit-nya pun relatif sedikit. Seiring dengan perkembangan zaman, pertunjukan Wayang tidak kalah juga dengan kesenian lainnya, bahkan Wayang menjadi kesenian yang sangat mahal dibanding dengan seni pertunjukan lainnya.

\section{2) Perabot Fisik Pertunjukan Wayang}

Perabot fisik dalam pertunjukan Wayang aplikasinya terdiri atas dua golongan, yaitu perabot fisik utama dan perabot fisik pendukung. Perabot fisik utama, merupakan perangkat yang harus dipenuhi dalam suatu pertunjukan Wayang, karena jika 
kurang salah satu di antaranya akan sangat mengganggu jalannya pertunjukan, contoh: Gamelan, Wayang, Keprak, Cempala, Kelir, Blencong, dan sebagainya.

Wayang sebagai representasi tokoh atau karakter, di tata dalam bentuk Simpingan kanan dan kiri membentuk kesan estetik dan berfungsi sebagai pembatas Jagading Wayang. Adapun Wayang yang ditampilkan berperan sebagai gambaran tokohtokoh atau benda-benda tertentu. Satu set Wayang dalam satu kotak terdiri atas: Wayang Simpingan, Wayang Dhudhahan, dan Wayang Ricikan (Sumanto dkk, 2005: 7).

Perabot fisik pendukung keberadaannya tidak mutlak harus ada, tetapi keberadaannya mendukung pertunjukannya menjadi lebih sempurna, seperti: sound system, sound effect, simbal, drum, perangkat musik non Gamelan, dan lain-lainnya.

\section{3) Perabot Non Fisik/Unsur-Unsur Garap Pakeliran}

Perabot non fisik adalah unsur-unsur yang nir kasat mata, berupa ide atau gagasan yang diekspresikan melalui pengolahan medium yang sesuai dengan kebutuhan. Unsur-unsur garap pakeliran terdiri atas 3 (tiga) jenis, yaitu: (1) Catur, (2) Sabet, dan (3) Iringan Pakeliran. Pada dasarnya antara perabot fisik dan unsur-unsur garap, merupakan satu kesatuan yang tidak dapat dipisah-pisahkan. Perabot garap berperan sebagai sarana ekspresi dari unsur-unsur garap, sedangkan unsur-unsur garap akan berarti apabila diungkapkan lewat bentuk-bentuk ekspresi sesuai dengan tuntutan suasananya.

Akumulasi dari berbagai unsur garap tersebut diwujudkan dalam satu kesatuan garap sajian yang berupa lakon. Di sini Wayang memiliki repertoar lakon paling lengkap di antara berbagai bentuk dra- ma yang ada di dunia. Berbagai lakon dalam pertunjukan Wayang pada dasarnya mengisahkan insiden-insiden yang dialami oleh manusia dalam hidupnya, sementara insiden-insiden di dalam Wayang tidak pernah berdiri sendiri tetapi saling berhubungan antara satu dengan yang lain. Beberapa contoh di antaranya kisah Kumbakarna dan Karna yang loyal terhadap prinsip-prinsip politiknya, tidak lepas dari kisah Wibisana dan Sanjaya yang loyal terhadap prinsip-prinsip moralnya. Kisah kepahlawanan Pandawa tidak lepas dari kisah kelicikan Kurawa, dan seterusnya. Dari kisah dan insiden-insiden itu dapat ditarik garis ke atas untuk mendapatkan tema pokok yang dominan dalam Wayang. Kesimpulannya adalah bahwa pada setiap makhluk ataupun benda selalu terdapat dua dasar yang saling berlawanan tetapi sekaligus saling melengkapi (Amir Hasyim, 1991: 64).

\section{4) Ringkasan Cerita Begawan Ciptaning}

Arjuna bertapa di Gunung Indrakila dengan gelar Begawan Ciptaning. Tujuan Arjuna bertapa adalah memohon petunjuk dewata demi kesuksesan Pandawa di masa depan, agar mendapatkan kembali tahta Kerajaan Indraprastha yang telah dirampas oleh Kurawa. Ciptaning seorang satria yang bertindak sebagai pendeta mengundang kekhawatiran para dewa, termasuk salah satunya adalah Bathara Guru dan Indra. Segala cobaan dikirim oleh Dewa Guru untuk menguji keimanan Arjuna, ternyata tiada satupun godaan yang mempan terhadap ketegaran jiwa Sang Ciptaning. Raja Manimangtaka Sang Niwatakawaca cemburu buta terhadap keberadaan Ciptaning, maka segera mengirim Mamangmurka agar membunuhnya. Namun dalam perjalanan 
Mamangmurka tidak mendapatkan hasil bahkan mati dalam wujud seekor babi hutan. Bathara Guru meluluskan segala permintaan Arjuna, yang pada akhirnya Bathara Guru memberikan anugerah berupa senjata Pasupati, dan Arjuna diminta membunuh raja raksasa Niwatakawaca musuh para dewa. Atas nasehat Semar dan bantuan Supraba, Arjuna berhasil membunuh Niwatakawaca. Akhirnya Arjuna diangkat sebagai Raja di Tinjomaya merajai para bidadari dengan gelar Prabu Kariti (Soetarno, 2004).

\section{Pendidikan Budi Pekerti}

\section{1) Maksud Pendidikan Budi-Pekerti}

Budi-pekerti dapat diartikan sebagai perilaku, perangai, tabiat, akhlak atau watak yang muncul sebagai manifestasi akal dan perasaan seseorang, sehingga seseorang itu mampu menimbang mana yang baik dan mana yang buruk (Imam Budi Santoso, 2011: 100). Dengan kata lain budi pekerti dapat dimaknai sebagai cerminan konsistensi dan keselarasan antara batin, watak, sifat, serta daya pikir dan perilaku atau perbuatan manusia.

Jika disejajarkan dengan pengertian dalam bahasa Inggris, budi pekerti dapat diterjemahkan sebagai moralitas yang mencakup beberapa pengertian seperti: adat istiadat, sopan santun, dan perilaku. Akan tetapi pengertian budi pekerti secara hakiki adalah perilaku. Adapun dalam draft kurikulum berbasis kompetensi (2001), budi pekerti berisi tentang nilainilai perilaku manusia yang dapat diukur kebaikan dan keburukannya melalui norma agama, norma hukum, tata krama, sopan santun, norma budaya, dan adat istiadat masyarakat. Budi-pekerti akan mengidentifikasi perilaku positif yang diharapkan dapat terwujud dalam perbuatan, perkataan, pikiran, sikap, perasaan, dan kepribadian peserta didik (Nurul Zuriah, 2007: 17).

\section{2) Kondisi Pendidikan Budi-Pekerti}

Mayarakat Indonesia yang dilanda krisis di berbagai dimensi ujung-ujungnya adalah krisis moral. Tidak banyak lagi masyarakat yang menghargai nilai-nilai luhur peninggalan para pendahulu, baik nilai ideologi, nilai sejarah, nilai moral, maupun nilai-nilai kehidupan lainnya. Generasi muda mengabaikan berbagai keteladan yang ada dalam budaya bangsa, karena dianggap kuno dan ketinggalan zaman.

Tuntutan untuk menyelenggarakan pendidikan budi pekerti dipandang perlu atas dasar tiga hal yang menjadi pertimbangan. Pertama, semakin melemahnya ikatan keluarga. Secara tradisional, keluarga yang merupakan guru pertama bagi setiap anak, telah kehilangan fungsinya. Akibatnya terjadi semacam kekosongan moral di dalam perkembangan hidup anak. Banyak anak terlantar karena kehancuran keluarga. Perceraian orang tua menjadi hal biasa, pada hal itu sangat memukul emosional anak dan mendorong ke arah kelainan pada kelakuan anak. Kedua, adanya kecenderungan negatif ala kehidupan remaja dewasa ini. Di kota-kota besar utamanya, sering terjadi perkelahian, tawuran antar remaja, anak-anak usia SMA, tawuran di kalangan mahasiswa, bahkan merembet menjadi tawuran antar penduduk kampung. Para generasi muda telah kehilangan pegangan hidup dan keteladanan perilaku etis. Mereka kehilangan model figur orang dewasa yang patut digugu dan ditiru. Ketiga, 
adanya kesadaran kembali akan perlunya nilai-nilai etik, moral, dan budi pekerti dewasa ini. Akhir-akhir ini telah muncul kecenderungan masyarakat yang mulai menyadari bahwa masing-masing masyarakat memiliki kearifan tentang adanya moralitas dasar yang esensial dalam kelangsungan hidup bermasyarakat. Oleh sebab itu, para orang tua dan para pendidik harus mendorong tumbuhnya moralitas dasar dengan cara mengajarkan kepada generasi muda, baik secara langsung maupun tidak langsung, agar mereka menghormati nilai-nilai tersebut (Nurul Zuriah, 2007: 10).

Masa depan kehidupan suatu bangsa akan sangat ditentukan oleh fondamen yang telah dibangun sejak awal oleh para pendahulunya. Selain itu sikap konservatif dan inovatif yang didasarkan pada ideologi dan konstitusi secara mantap akan menjadi wahana kemajuan dan berkembangnya suatu negara. Artinya bahwa kualitas generasi suatu bangsa menjadi tolok ukur masa depan bangsa dan negara. Kualitas generasi itu dapat dilihat dari budi pekerti yang merupakan cerminan dari moralitas bangsa itu sendiri. Kenyataannya bangsa Indonesia saat ini boleh dikatakan sangat memprihatinkan, karena semakin tipisnya pendidikan budi pekerti.

\section{3) Upaya Pendidikan Budi Pekerti}

Guna mengantisipasi semakin merosotnya moralitas bangsa yang besar ini, kiranya sangat penting diupayakan penanaman pendidikan budi pekerti secara terus-menerus terhadap generasi penerus bangsa ini. Wayang merupakan bentuk seni pertunjukan yang mampu menyampaikan pendidikan budi pekerti kepada masyarakat. Ditinjau dari asal mulanya, seni pertunjukan Wayang me- rupakan hasil karya dari kegiatan religius masyarakat Jawa pada zamannya, karena cerita Wayang dipandang sangat sesuai untuk menyampaikan hal-hal ke-ilahian (Zoetmulder, 1990:285). Pertunjukan Wayang cukup merakyat dan paling khas di kalangan masyarakat Jawa. Orang Jawa pada umumnya memandang pertunjukan Wayang sebagai 'cermin kehidupan' atau wewayanganing urip.

Pertunjukan Wayang mampu memukau penonton hingga perasaan penonton itu terbawa masuk ke dalam suasana pakeliran, sebagaimana ditemukan dalam Serat Arjuna Wiwaha pupuh $V$ Çikarini pada 9, yang berbunyi sebagai berikut.

"...ananonton ringgit manangis as êkêl muda hidhêpan huwus wruh towin ya(n) walulang inukir molah angucap atur ning wwa(ng) $t r$ ş neng wişaya malah $\bar{a}$ tan wi(hi)ka(nhi)na, r(i)tattwa(y) a.n (m)āyā sahana-hana ning bhawā siluman..."(Wiryamartana dalam Suyanto 2009: 4).

Terjemahannya kurang lebih demikian

("...ada orang menonton Wayang menangis terisak-isak itu sikap orang bodoh, padahal sudah tahu bahwa itu hanyalah kulit yang diukir, digerakkan dan diucapkan (oleh dalang), itulah sebagai orang yang terbelenggu dalam keduniawian dan tersesat hatinya, yang dilihat itu sebenarnya hanyalah semu belaka bagaikan sulapan...").

Hal itu terjadi karena kepiawaian seorang dalang dalam menyajikan pakelirannya. Di zaman modern ini banyak muncul generasi seniman dalang, baik lulusan pendidikan menengah maupun pendidikan tinggi, tentunya bukan suatu hal yang mustahil apabila pada masa kini terdapat dalang-dalang yang lebih mampu menyampaikan nilai-nilai budi pekerti 
itu melalui pertunjukan Wayang sesuai dengan situasi dan tuntutan zaman.

\section{4) Peranan Pertunjukan Wayang dalam Pendidikan Budi-Pekerti}

Pertunjukan Wayang menggelarkan secara luas mengenai hakikat kehidupan manusia dan alam di sekitarnya serta rahasia hidup beserta kehidupan manusia. Melalui pertunjukan Wayang manusia diseyogyakan merenungkan hidup dan kehidupan ini, utamanya mengenai kehidupan pribadi yang berhubungan dengan hakikat keberadaannya (sangkan paraning dumadi) dan apa yang dapat dilakukan dalam menghadapi kehidupan di dunia yang fana ini.

Sebagai seni pertunjukan, Wayang tidak dapat lepas dari hakikat pertunjukan itu sendiri, di antaranya selain mengandung aspek filsafati berupa nilai-nilai ajaran hidup, juga terdapat kesan-kesan yang berupa hiburan semata. Hal ini lazim dikatakan oleh masyarakat Jawa bahwa Wayang selain sebagai tontonan juga menjadi tuntunan; maksudnya bahwa selain sebagai hiburan Wayang juga sebagai penyampai pesan moral. Sejauh mana orang memberikan makna terhadap pertunjukan Wayang itu sesungguhnya bergantung pada pemahaman dan kepentingan tiap-tiap individu terhadap Wayang.

Sekarang perlu disadari bahwa generasi muda dalam mengapresiasi dan memahami Wayang tidak seperti generasi masa lampau, karena situasi dan kondisi budaya yang melatarbelakangi mereka pun sangat berbeda. Perhatian semacam itu wajar, karena di era globalisasi ini telah terjadi pencarian nilai-nilai tradisional di segala bidang, termasuk nilai dalam Wayang. Menyikapi fenomena seperti ini, maka pertunjukan Wayang perlu di- upayakan selalu adanya kreasi dan inovasi secara terus-menerus sesuai dengan perkembangan zaman, agar Wayang selalu menemukan aktualitasnya di masa depan.

\section{Nilai-Nilai dalam Pertunjukan Wayang}

\section{1) Nilai Filosofis}

Dunia telah mengakui bahwa salah satu cermin kebudayaan orang Jawa yang edipeni dan adiluhung itu diprojeksikan dalam pertunjukan Wayang Kulit. Wayang merupakan manifestasi dari pandangan hidup Jawa (falsafah Jawa). Hal itu dapat dirasakan dalam kandungan nilai-nilai filosofis yang tersirat dalam lakon-lakon Wayang. Nilai-nilai itu diungkapkan secara total melalui kiasan-kiasan yang mengandung nilai-nilai kehidupan dan bersifat universal; baik itu berupa karya sastra, gubahan cerita, lukisan boneka, maupun pada keseluruhan pertunjukan Wayang itu sendiri.

Konsep Edi adalah pencitraan dari sikap yang ditangkap melalui penghayatan rasa yang terkait dengan etika dan moralitas yang berkaitan dengan aspek 'bener' dan 'pener' serta didasarkan padasikap religius yang tercermin pada 'peni'; sifat ke arah edi lebih condong pada maskulinitas, seperti mengarah pada perwujudan yang 'bagus' atau besus, cakrak, cakrik, atau rengguh. Menghayati karakter-karakter yang gagah, kuat, dan tekanan suara yang rendah dan mantap. Maka ki dalang dalam memainkan Wayang diperlukan keterampilan yang membuat orang terpesona. Konsep Peni adalah citraan estetik yang menunjukkan antara wujud, sikap, dan nilai intrinsik (konseptual, intelektualitas, dan religiusitas) maka seringkali digabungkan menjadi Edipeni. 
Adi dalam bahasa Jawa dapat diartikan sebagai citraan kualitas yang berhubungan dengan moral, karakter, dan kepribadian. Luhung sama dengan luhur yang dapat diartikan sebagai citraan status atau strata nilai dalam kehidupan. Konsep-konsep demikian merupakan akumulasi dari rasa penghayatan yang mendasari manusia untuk merenungi sebuah kehidupan yang tergelar dalam pertunjukan Wayang.

Pertunjukan Wayang juga mengandung ajaran yang bersinggungan dengan hakikat manusia secara mendasar, di antaranya ialah ajaran moral yang mencakup moral pribadi, moral sosial, dan moral religius (Samsunu Yuli Nugroho, 2005: 11). Pertunjukan Wayang menggelarkan hakikat kehidupan manusia dan segala sesuatu di sekitarnya serta rahasia hidup beserta kehidupan manusia. Melalui pertunjukan Wayang manusia diseyogyakan merenungkan hidup dan kehidupan ini utamanya mengenai kehidupan pribadi yang berhubungan dengan sangkan paraning dumadi dan apa yang dapat dilakukan dalam menghadapi kehidupan di dunia yang durasinya tidak lama ini. Pertunjukan Wayang Kulit pada dasarnya merupakan lambang perjuangan batin, dalam berkompetisi, antara prinsip baik dan prinsip buruk di dalam kehidupan manusia pada umumnya, atau dengan istilah lain antara perihal mistik dan magis.

\section{2) Nilai Budi Pekerti}

Nilai budi pekerti dapat diartikan sesuatu yang menjadi harapan, cita-cita, yang diyakini untuk dicapai oleh setiap manusia guna memiliki kepribadian yang baik dan berbudi luhur. Dalam kerangka mencapai harapan itu, manusia memerlukan acuan di samping ajaran agama, masih diperlukan berbagai suri teladan yang berbasis kultural.

Pertunjukan Wayang diperkirakan sejak sebelum abad XI sudah dimaknai sebagai simbol-simbol keteladanan dalam kehidupan masyarakat Jawa pada waktu itu. Dengan munculnya cerita-cerita pewayangan di dalam seni pertunjukan, maka peran karya-karya sastra pewayangan pun berkembang sesuai dengan perkembangan budaya masyarakatnya.

Ajaran budi pekerti dalam Wayang tertuang di dalam jalinan kisah yang dipentaskan oleh dalang selama semalam suntuk atau kurang lebih tujuh jam durasi pertunjukan. Di dalam peristiwa atau kejadian pada lakon Wayang itu sendiri sudah terkandung ajaran budi pekerti. Budya Pradipta menegaskan bahwa budi pekerti harus dipahamkan sebagai laku manusia untuk menjalankan sifat-sifat yang baik (Budya Pradipta, 2005: VIII-3).

Budi yang dipekertikan dalam kehidupan nyata sehari-hari atau pekerti yang berbudi merupakan wujud dari cipta, rasa, dan karsa seseorang. Hal demikian masih belum nampak karena masih berada dalam cipta, rasa, karsa manusia kecuali jika sudah diaktualisasikan ke dalam kenyataan berupa sikap, kata, dan perbuatan. Dari situ manusia dapat memotret struktur sikap, kata dan perbuatan seseorang; jujur dan tidak jujur-lugu dan tidak lugu-dengki dan tidak dengki-iri dan tidak iri, dan sebagainya (2005: VIII-5).

\section{Pendidikan Budi-Pekerti Melalui Per- tunjukan Wayang}

\section{1) Wayang sebagai Wahana Pendidikan Budi-Pekerti}

Wayang Kulit merupakan salah satu harta kultural yang menjadi media unik bagi 
masyarakat Jawa untuk mengekspresikan cita-cita hidupnya. Kecerdasan lokal genius Jawa dalam mengelaborasi berbagai pandangan luhur budaya lain (Hindu/Budha dan pada akhirnya Islam) menjadikan masyarakat Jawa kaya akan berbagai nilainilai kehidupan. Pertunjukan Wayang yang kaya akan syarat pesan moral membuat pertunjukan Wayang menjadi sangat penting untuk dijadikan sebagai media pendidikan pada anak-anak dan generasi penerus bangsa.

Menanamkan kembali pelajaran Budi Pekerti melalui pertunjukan Wayang merupakan bentuk pendidikan yang cerdas dan bermanfaat, karena di dalam Wayang terdapat pendidikan karakter dan sarana edukasi yang bersifat rekreatif simbolis dan dapat merangsang imajinasi anak untuk mengenali lebih jauh serta mengakrabi cerita di dalam pertunjukan Wayang. Hal ini akan membuat anak lebih tertarik dengan mempermudah bahasa ungkapnya dan melibatkan anak lebih jauh dalam pertunjukan Wayang, membuat anak mengetahui tentang nilai-nilai kearifan lokal yang secara tidak sadar dipelajarinya melalui lakon Wayang yang disaksikannya. Dengan demikian cerita Wayang telah membantu merangsang perkembangan moral mereka.

Pertunjukan Wayang, lepas dari Wayang apa dan siapa dalangnya, sebenarnya telah mampu mengajarkan nilai-nilai budi pekerti melalui semua unsur pertunjukkannya. Wayang bagi Bangsa Nusantara telah mendapatkan tempat di hati masyarakat dalam kurun waktu cukup lama. Nilai-nilai yang diekspos melalui pertunjukan Wayang merupakan akumulasi nilai kebudayaan Jawa, sehingga Wayang tidak hanya semata-mata sebagai salah satu wujud kesenian Jawa, melainkan sudah men- jadi manifestasi kebudayaan orang Jawa. Dengan demikian bukan suatu yang mustahil bahwa Wayang secara falsafati dipandang sebagai cermin kehidupan orang Jawa atau wewayanganing urip (Suyanto, 2009: 2).

Pertunjukan Wayang di mata orang Jawa bukan sekedar tontonan melainkan juga sebagai tuntunan, karena di dalamnya mengandung ajaran budi pekerti beserta pesan-pesan moral yang tidak bersifat dogmatis. Artinya, penonton Wayang dihadapkan pada sejumlah pilihan yang dianggap sesuai dengan dirinya masingmasing. Melalui pertunjukan Wayang Kulit digambarkan tindakan manusia yang pantas dan yang tidak pantas beserta konsekuensinya masing-masing, yakni hukum sebab-akibat. Meskipun dalam cerita Wayang Jawa terdapat tokoh-tokoh protagonis dan antagonis, tetapi pembagian ini tidak mutlak, yang jelas dalam konvensi pertunjukan Wayang selalu membeberkan norma-norma kehidupan, bahwa kejahatan akan selalu diadili oleh kebenaran (Sura sudira jaya ni kanang rat syuh brastha tekap ulah dharmastuti).

Ajaran-ajaran moral dalam pertunjukan Wayang selain tersirat dalam repertoar lakon dan posisi penempatan tokoh tersebut, juga tersurat dalam bentuk ungkapan wacana Wayang berupa dialog dan wejangan-wejangan tokoh tertentu (biasanya tokoh-tokoh arif seperti Bisma dan Abiy pitungkas asa) dan/atau tampak dalam ungkapan gerak Wayang (sabet). Melalui dua media ini, penonton dihadapkan pada sejumlah ajaran moral tentang unggah-ungguh, suba-sita, tata krama, tata susila, budi pekerti, pranatan, pituduh, wewaler, dan pitungkas. Pesan-pesan moral ini sebagian besar masih relevan dengan kondisi zaman. 
Nilai-nilai budi pekerti manusia Indonesia pada garis besarnya terangkum dalam lima unsur sila yang terkandung di dalam Pancasila sebagai falsafah hidup dan norma kesusilaan yang berlaku di Indonesia hingga saat ini. Pancasila sebagai pedoman hidup bernegara dan pandangan hidup Bangsa Indonesia merupakan ciri khas yang dapat membedakannya dengan bangsa lain. Pancasila adalah rangkuman tentang norma-norma yang mengatur tingkah laku dan perikehidupan bangsa sebagai refleksi dari tata nilai budi pekerti yang diidam-idamkan. Akan tetapi pada saat ini hal itu perlu dipertanyakan, apakah sebagian besar bangsa Indonesia masih berpegang pada ideologi Pancasila? Untuk menjawab pertanyaan itu agaknya bangsa ini perlu merenung kembali, dan perlu mencermati apa yang ada di dalam Wayang.

\section{2) Lakon Begawan Ciptaning untuk Pendidikan Budi Pekerti}

Arjuna melakukan tapa-brata tanpa pamrih, ia semata-mata beribadah dan beserah diri kepada Yang Maha Kuasa didasari keyakinan yang kuat dan tekad yang mantap, apa pun hasilnya ia akan menerimanya dengan ikhlas. Sebagai seorang pemimpin bangsa, Arjuna berusaha untuk selalu dapat mengoreksi diri sendiri (mawas diri), yang dilakukan dengan cara mendekatkan dirinya kepada Yang Maha Kuasa dengan laku tapa brata. Orang yang berkeyakinan seharusnya mempercayakan diri kepada bimbingan Yang llahiah dan taat (mituhu) kepada-Nya. Siapa yang bertindak demikian, dengan sendirinya akan menemukan sikap yang tepat dalam menyikapi semua permasalahan yang dihadapinya. Hal ini dikarenakan orang itu telah mampu menerima petunjuk Tuhan melalui isyarat-isyarat batiniah (sasmita jati).

Ketika Arjuna menghadapi Niwatakawaca, ia telah terdesak dalam peperangan, namun demikian karena tanggap dengan apa yang dikatakan oleh Semar, maka ia mampu menaklukkan Niwatakawaca. Semar adalah simbol kekuatan batiniah yang melekat pada diri Arjuna sendiri. Hal inilah yang dalam pandangan orang Jawa dikatakan bahwa orang hidup ini harus selalu eling, waspada, percaya, dan mituhu. Eling adalah sikap selalu mengingat adanya Tuhan, waspada,yaitu sikap mawas diri, percaya itu iman, dan mituhu adalah sikap takwa kepada Tuhan.

Pemahaman nilai budi pekerti bagi generasi muda diharapkan berpengaruh secara langsung terhadap pembinaan watak sabar, narima, rila, temen, dan prasaja. Sabar adalah salah satu ciri seorang pemimpin yang baik. Sikap sabar bukan berarti lemah dalam tindakan, tetapi justru tegar dan penuh hati-hati sehingga dalam mencapai tujuan tidak terdapat sandungan kerikil-kerikil tajam, karena pemimpin mampu selayaknya bersikap kepada rakyatnya. Narima adalah sikap berserah diri, tetapi bukan berarti pasif, melainkan sikap aktif mampu bereaksi secara rasional dalam menghadapi kesulitan hidup, tidak mudah putus asa ketika menerima kekecewaan. Rila adalah sikap ikhlas, bersedia melepas atau meluluhkan kekuatan serta beradaptasi dengan alam semesta sebagaimana yang telah ditentukan. Temen yakni sikap jujur yang berarti dapat mengandalkan janjinya. Orang yang bersikap jujur dengan sendirinya akan berwatak adil, hatinya akan penuh keberanian dan ketenteraman. Prasaja adalah sikap sederhana, tidak mengunggulkan diri, bahkan bersedia menganggap dirinya sendiri le- 
bih rendah dari pada orang lain.

Muara dari kepemilikan sikap-sikap tersebut di atas adalah manusia yang berbudi luhur. Budi luhur merupakan kebalikan dari budi asor, yaitu sikap manusia yang suka menggunjing, membenci, mencemooh, mencurigai, dalam bahasa Jawa dikenal dengan istilah: drengki, srei, jail, muthakil, dahwen, open, juweh, merketeh, dan sebagainya. Budi luhur berarti memiliki perasaan tepat bagaimana cara bersikap terhadap orang lain, apa yang harus dilakukan dan apa yang tidak harus dilakukan terhadap sesama. Orang yang berbudi luhur tidak hanya bersikap baik kepada orang yang berbudi baik saja, tetapi juga baik terhadap orang-orang yang buruk, sapa becik den beciki, sapa ala den beciki (Asep Rachmatullah, 2009: 53). Dalam konsep Jawa pemimpin diibaratkan orang tua, sebagai orang tua yang sanggup mengasuh anak-anaknya harus memiliki watak pradhah, artinya sikap yang mampu menampung berbagai hal baik berupa sanjungan, keluhan, maupun cemoohan, orang tua harus dapat mewadahi atau ngrengkuh dengan sikap yang arif dan bijaksana.

Seorang pemimpin mampu bersikap arif dan bijaksana apabila rajin belajar tentang norma-norma keutamaan (mardi kautaman). Selain itu pemimpin juga selalu mengolah jiwanya untuk mencapai kesempurnaan. Pengertian kesempurnaan dalam konteks ini bukan semata-mata mempelajari ilmu-ilmu gaib yang berhubungan dengan sangkan paraning dumadi, melainkan bagaimana seorang pemimpin mampu mengendalikan dirinya dalam keadaan yang selalu selaras, serasi, dan seimbang antara pribadi dan makarti (perbuatan). Lebih daripada itu, seorang pemimpin memiliki kewajiban memayu hayuning bawana, yaitu ikut bertanggung jawab melindungi keselamatan dunia.

Arjuna bertapa di Gunung Indrakila dengan sebutan Begawan Ciptaning, Begawan berarti raja/satria pertapa, Ciptaning berarti cipta yang jernih/wening. Hanya melalui cipta yang jernih dan wening-lah manusia akan mampu menerima petunjuk dari Yang Maha Kuasa (pituduh jati). Arjuna mendapatkan ujian dari dewa berupa godaan bidadari tujuh; tetapi Ciptaning tiada goyah sedikitpun dalam semadinya. Bahkan Ciptaning mampu menghempaskan para bidadari dari pertapaannya yang merupakan simbol keteguhan hati dan kesucian budi Ciptaning yang benar-benar mantap dalam keyakinannya.

Mamangmurka merupakan simbol kemungkaran hawa nafsu yang buruk. Wujud ketidaksempurnaan Mamangmurka sebagai makhluk menunjukkan sifatnya yang tiada sempurna pula. Mamangmurka dalam menjalankan tugasnya tanpa berpikir secara sehat, ia bertindak hanya terdorong oleh emosi dan amarahnya yang besar.

Keratarupa adalah wujud simbolik ujian Yang Maha Kuasa terhadap Arjuna. Tuhan dalam menguji umatnya dapat berupa apa saja dan dengan cara apa saja. Bathara Guru menguji kekuatan Arjuna, baik fisik maupun jiwanya melalui penyamarannya sebagai seorang pemburu bernama Keratarupa. Bathara Guru meyakini bahwa Ciptaning mampu memberantas musuh para dewa dan pantas menerima anugerah agung dari Yang Maha Kuasa. Di sinilah menyatunya cipta, rasa, dan karsa antara Arjuna dan Bathara Guru. Pasupati hanya dapat diminta melalui cipta yang wening (kaweninganing cipta), dan Pasupati inilah yang dapat digunakan untuk memberan- 
tas segala wujud kezoliman dan angkaramurka di dunia.

Keteguhan Arjuna dalam memegang kesetiaannya ternyata menuai hasil yang bermakna dan bermanfaat baik bagi diri Arjuna sendiri maupun semua keluarga Pandhawa. Ketaatan dan kepatuhan Arjuna terhadap petunjuk dan wewaler ibunya mampu mengantar Arjuna ke puncak kesuksesannya dalam meraih cita-cita.

\section{PENUTUP}

Lakon-lakon dalam pertunjukan Wayang pada umumnya mengandung nilai-nilai budi pekerti, tetapi juga terdapat lakon-lakon yang secara khusus membeberkan pendidikan budi pekerti, salah satunya adalah Lakon Begawan Ciptaning. Munculnya tulisan-tulisan tentang pendidikan budi pekerti baik melalui media pertunjukan Wayang maupun yang lainnya diharapkan dapat membangkitkan kesadaran masyarakat terhadap pentingnya pembangunan moralitas dan budi pekerti bagi generasi bangsa Bangsa Indonesia tercinta ini.

\section{DAFTAR PUSTAKA}

Amir Hazim

1997 Nilai-Nilai Etis Wayang. Jakarta: Pustaka Sinar Harapan.

Asep Rahmatullah

2011 Filsafat Hidup Orang Jawa. Yogyakarta: Siasat Pustaka.

Budya Pradipta

2005 "Nilai-Nilai Budi Pekerti dalam Wayang". Makalah. Kongres PeWayangan di Yogyakarta.
I Kuntara Wiryamartana

1999 Arjunawiwaha. Yogyakarta: Duta Wacana University.

Imam Budi Santoso

2011 Saripati Ajaran Hidup Dahsyat dari Jagad Wayang. Jakarta: Flash Book.

Koentjaraningrat

1981 Manusia dan Kebudayaan di Indonesia. Jakarta: Jambatan.

Nurul Zuriah

2007 Pendidikan Moral \& Budi Pekerti dalam Prespektif Perubahan. Jakarta: Bumi Aksara.

Samsunu Yuli Nugroho

t.th Semar \& Filsafat Ketuhanan. Yogjakarta: Gelombang Pasang.

Soetarno

2000 "Laporan Penelitian Filsafat Wayang". Surakarta: Kerjasama ISI Surakarta dan SENAWANGI.

Sumanto, Bambang Murtiyoso, Suyanto, Kuwato

2005 Teori Pedalangan Bunga Rampai Unsur-Unsur Garap Pakeliran. Surakarta: STSI Press.

Suyanto

2009 Nilai Kepemimpinan Lakon Wahyu Makutharama dalam Prespektif Metafisika. Surakarta: ISI Press.

Zoetmulder

1990 Manunggaling Kawula Gusti Pantheisme dan Monisme dalam Sastra Suluk Jawa. Jogyakarta: Kanisius. 